\title{
Isolation and Identification of Dominant Bacteria from Raw Donkey Milk Produced in a Region of Morocco by QIIME 2 and Evaluation of Their Antibacterial Activity
}

\author{
Reda Derdak $\left(\mathbb{D},{ }^{1}\right.$ Javier Quinteiro ${ }^{D},{ }^{2}$ Souraya Sakoui ${ }^{(D)},{ }^{1}$ Boutaina Addoum ${ }^{D}{ }^{1}$ \\ Jorge Rodríguez Castro, ${ }^{2}$ Manuel Rey Méndez $\left(\mathbb{0},{ }^{2}\right.$ Abdelaziz Soukri $\odot{ }^{\circ},{ }^{1}$ \\ and Bouchra El Khalfi ${ }^{1}{ }^{1}$ \\ ${ }^{1}$ Laboratory of Physiopathology, Molecular Genetics \& Biotechnology, Ain Chock Faculty of Sciences, \\ Health and Biotechnology Research Center, Hassan II University of Casablanca, B.P 5366 Maarif, Casablanca, Morocco \\ ${ }^{2}$ Laboratory of Molecular Systematics, Department of Biochemistry \& Molecular Biology, \\ CIBUS University of Santiago de Compostela, Santiago, Spain
}

Correspondence should be addressed to Bouchra El Khalf; bouchra.elkhalfi@gmail.com

Received 24 December 2020; Revised 21 April 2021; Accepted 30 July 2021; Published 10 August 2021

Academic Editor: Juei Tang Cheng

Copyright (C) 2021 Reda Derdak et al. This is an open access article distributed under the Creative Commons Attribution License, which permits unrestricted use, distribution, and reproduction in any medium, provided the original work is properly cited.

Recently, the interest in donkey milk has increased considerably because it proved high nutritive and functional values of their ingredients. Its chemical composition is widely studied, but its microbiota, especially lactic acid bacteria, remains less studied. This study focuses on analyzing, isolating, and identifying lactic acid bacteria and evaluating their capacity to produce biomolecules with antibacterial activity. Among 44 strains identified, 43 are Gram-positive, and most are catalase-negative and cocci-shaped. Five strains were selected to evaluate their antibacterial activity against Listeria monocytogenes, Staphylococcus aureus, and Escherichia coli. Different induction methods allowed to amplify the antibacterial effects against these pathogenic strains.

\section{Introduction}

In recent decades, overuse and misuse of antibiotics has led to the emergence and spread of high bacterial resistance, making difficult to treat infections involving tremendous research efforts by the medical and scientific community $[1,2]$. This concern led the international authorities to adopt concerted plans to optimize the use of antibiotics and to promote the research for alternative solutions [3]. Since, research is focused in the searching for a new bioactive molecule with antibiotic capabilities.

In fact, living organisms have developed an immense molecular diversity, containing ubiquitous low molecular weight secondary metabolites isolated from plants, insects, marine organisms, and other microorganisms [4-6], including lactic acid bacteria (LAB) [5].

$\mathrm{LAB}$ are microorganisms forming a group composed of bacilli and cocci [7]. The common characteristic of these bacteria is the production of lactic acid, which is the end product of the fermentation process of several sugars [8]. In addition, these germs represent a potential source of several metabolites with antimicrobial and antifungal activities like organic acids [9], reuterin, hydrogen peroxide, diacetyl [5] carbon dioxide, and bacteriocins [10-13]. They are present in different microbial biotopes such as soil, plants, the digestive system of human, and dairy products $[14,15]$.

Among these dairy products, we chose donkey milk (DM), which has attracted scientists' attention because of its convincing nutritive and functional elements $[16,17]$. Because of its chemical composition similar to human milk $[18,19]$, it has therefore been used as an adequate alternative for infants with multiple food intolerances and allergies. Recently, fermented products made from DM have been proposed as important sources of probiotics and antioxidants, which have several health benefits $[17,19,20]$. 
Whereas chemical composition of donkey milk is very much studied, its microbiota remains less studied; therefore, this study focused (i) to analyze basic DM parameters, (ii) to isolate and identify LAB, (iii) and finally evaluate their antibacterial effect.

\section{Materials and Methods}

2.1. Sampling Milk. Donkey's milk sample was harvested from animals located at the Beni Mellal region, under appropriate aseptic conditions. The milk was collected in a sterile vial and transported to the laboratory at $4^{\circ} \mathrm{C}$.

\subsection{Milk Analysis}

2.2.1. Measurement of Milk Stability. The milk stability tests are employed to evaluate the quality of the milk and to verify the absence of chemical contamination. The tests performed are the (i) $80 \% \mathrm{v} / \mathrm{v}$ ethyl alcohol test, (ii) Ramsdell test, (iii) boiling test, and (iv) formalin test [21].

2.2.2. Measurement of Some Physicochemical Parameters. The milk $\mathrm{pH}$ was determined using a $\mathrm{pH}$ meter [21], the acidity was determined by using a methanolic solution of phenolphthalein as a colored indicator [21], and the density was determined according to Afnor [22].

The dry matter content was estimated by evaporation in a waterbath at $70^{\circ} \mathrm{C}$ and then oven drying for 3 hours [21].

2.3. Isolation of Bacteria. The isolation was carried out by the successive depletion method on MRS medium agar and M17 medium agar (Biokar diagnostics). Seven subcultures were made until isolation of pure colonies.

2.3.1. Phenotypic and Biochemical Identification. Gram stain was performed using the standard bacteriological procedure [23].

(1) Catalase Test. A colony was removed and then emulsified on a slide containing a drop of $3 \% \mathrm{v} / \mathrm{v}$ hydrogen peroxide.

(2) Kligler Test. Using a sterile needle, a colony was sown by simple pitting at the bottom of the agar tube (Kligler medium, Biokar diagnostics) and by tight streaks on the inclined surface of the tube, before being incubating at $32^{\circ} \mathrm{C}$ for $24 \mathrm{~h}$. This double inoculation permits bacterial growth on the aerobic surface and in the largely anaerobic part of the tube.

(3) Mobility Mannitol Test. Using a sterile needle, a colony was removed and introduced into the medium up to $1 \mathrm{~cm}$ from the bottom of the tube, keeping the loop in the same trajectory at the entrance and at the outlet of the agar medium. Incubation was performed at $32^{\circ} \mathrm{C}$ for $24 \mathrm{~h}$.

\subsection{Molecular Identification}

2.4.1. DNA Extraction. DNA extraction was performed by a chloroform phenol method described elsewhere [24]. Quantitation of the DNA was performed using NanoDrop Lite Spectrophotometer (Thermo Fisher Scientific).

2.4.2. PCR Amplification and Sequencing. Total DNA extracted from samples was used as a template for the amplification of a fragment of the $16 \mathrm{~S}$ ribosomal DNA by polymerase chain reaction (PCR). Amplification was performed using the highly conserved universal primers: $\mathrm{Fd} 1$ $5^{\prime}$-AGAGTTTGATCCTGGCTCAG-3 ${ }^{\prime}$ and RP2 $5^{\prime}$ ACGGCTACCTTGTTACGACTT-3' [25].

The PCR reactions were carried out using a TC1000-G thermocycler (DLAB Scientific), in a total volume of $15 \mu \mathrm{L}$ containing approximately $100 \mathrm{ng}$ of genomic DNA, $0.3 \mu \mathrm{L}$ of each $10 \mathrm{~mm}$ dNTP (Promega), $3 \mu \mathrm{l}$ of $5 \mathrm{X}$ buffer (Promega), $0.9 \mu \mathrm{L}$ of $25 \mathrm{~mm} \mathrm{MgCl}_{2}$ (Promega), $0.12 \mu \mathrm{L}$ of each $10 \mathrm{~mm}$ primer, and $0.075 \mu \mathrm{L}$ of Taq polymerase $5 \mathrm{U}$ (Promega). The PCR was programmed as follows: $95^{\circ} \mathrm{C}, 2^{\prime} /\left(95^{\circ} \mathrm{C}, 40^{\prime \prime}-55^{\circ} \mathrm{C}\right.$, $\left.40^{\prime \prime}-72^{\circ} \mathrm{C}, 1^{\prime}\right) \times 35 ; 72^{\circ} \mathrm{C} / 5^{\prime} / 4^{\circ} \mathrm{C}$.

The PCR products were purified using the ExoSAP-IT purification kit (GE Healthcare), and sequencing was performed with the BigDye Terminator Kit version 1.0 (Applied Biosystems).

Sequencing products were separated and detected in a 3730xl Genetic Analyzer (Applied Biosystems). Chromatogram revision and trimming was performed with the sequence scanner (Applied Biosystems), and alignment was obtained from ClustalX implemented in BioEdit [26].

2.4.3. Taxonomic Inference. The $16 \mathrm{SrDNA}$ sequences were analyzed with QIIME 22019.10 [27]. The Sanger sequences in FASTA format were imported into a QIIME2 artefact, aligned with MAFFT [28], and a phylogenetic tree was inferred using fasttree2 [29]. The assignment to diverse taxonomic levels was performed with the q2-feature-classifier [30] and classify-sklearn Näive Bayes taxonomy classifier against the Green genes 13_8 99\% OTUs reference sequences [31]. In addition, each sequence was analyzed using the alignment tool BLASTN [32].

\subsection{Antibacterial Activity}

2.5.1. Strains and Growth Condition. Among the strains identified, Aerococcus viridans, Enterococcus faecalis, Enterococcus viikkiensis, Enterococcus devriesei, and Leuconostoc mesenteroides were selected to evaluate their ability to produce biological active molecules. These lactic acid bacteria were cultured in MRS medium (Biokar diagnostics) and incubated $24 \mathrm{~h}$ at $32^{\circ} \mathrm{C}$.

The pathogenic strains Listeria monocytogenes, Staphylococcus aureus, and Escherichia coli were used as indicator strains, and these strains were cultured in the Luria-Bertani (LB) medium and incubated at $37^{\circ} \mathrm{C}$ for $24 \mathrm{~h}$. 
2.5.2. Optimization Assay. In order to optimize and evaluate their capacity to produce biomolecules with antimicrobial activity, the LAB were placed under different culture conditions, according to the values reported in Table 1 . The incubation was performed at $32^{\circ} \mathrm{C}$ for $24 \mathrm{~h}$.

2.5.3. Diffusion of Agar. The well diffusion method was carried out following a modification of the Schillinger and Lücke [33] method. Petri dishes containing $20 \mathrm{~mL}$ of the LB medium supplemented with agar $0.6 \%(w / v)$ are inoculated aseptically a $10^{6} \mathrm{CFU} / \mathrm{mL}$ bacteria suspension. After solidification, $5 \mathrm{~mm}$ wells were created. Then, $50 \mu \mathrm{L}$ of each supernatant was deposited in each well. All dishes were put at $4^{\circ} \mathrm{C}$ for 4 hours and then incubated at $37^{\circ} \mathrm{C}$ overnight. Two negative controls were used; One containing only the indicator strain, and the other, the modified MRS medium (Table 1), to test the effect on the indicator strains. The presence of an inhibition zone $(\mathrm{Zi})$ around the wells is synonymous with the production of antimicrobial substances (one or more). $\mathrm{Zi}$ is determined following formula:

$$
\mathrm{Zi}=\text { diameter of the } \mathrm{Zi} \text { obtained }- \text { diameter of the well }(5 \mathrm{~mm}) \text {. }
$$

\section{Results and Discussion}

3.1. Milk Analysis. Milk stability tests have shown that analyzed milk is stable and does not contain any chemical contamination, such as formalin and alcohol like found by other studies [34].

Physicochemical parameters are given in Table 2. The titratable acidity of the milk is $16.3^{\circ} \mathrm{D}$, which explains that the milk is not altered and that the $\mathrm{pH}$ of the $\mathrm{DM}$ is neutral; this is due to the low content in casein and phosphate [35]. This result is similar to those found by Guo et al. and Salimei $[36,37]$. Comparing with other milks, we find that the $\mathrm{pH}$ of DM is similar to human milk $(7-7,3)$ [19], but more basic than camel milk, cow milk, and goat milk, which is around 6 [38].

3.2. Microbiological Identification. The phenotypic and biochemical characteristics were evaluated for the 44 isolated bacterial strains. The morphological results showed that all these bacteria are Gram-positive, except for one strain, and with dominance for cocci shapes. Most strains are catalase negative, whereas only 17 strains showed a positive result (Table S1, supplementary material). Our results are consistent with those found by de Garnica et al. [39].

The strains were tested for their ability to use glucose and lactose in the Kligler medium [24]. All strains fermented glucose without gas production, as expected from homofermentary bacteria. None of the tested strains were able to produce $\mathrm{H}_{2} \mathrm{~S}$, the majority ferment lactose and mannitol, and they are immobile $[24,39]$.
The high level of lysozyme in DM selects for the presence of Gram-positive bacteria, as observed from the characterization of analyzed samples [40].

3.3. Molecular Identification. The molecular identification of LAB from $16 \mathrm{~S}$ rDNA sequences showed the existence of 9 groups of bacteria (Figure 1), resolved at different taxonomic levels.

A first group is characterized by the genus Bacillus with 15 isolates, with a dominance of the species Bacillus amyloliquefaciens, as inferred from the BLASTN search. A second group was characterized by the genus Enterococcus with 9 isolates. A third group included 7 isolates from the genus Staphylococcus. Three isolated from the identified Aerococcus viridans were included in a fourth group. A fifth group was characterized by the genus Leuconostoc with a frequency of 2 isolates. The other groups included a single isolate, Rothia, Acinetobacter, and Streptococcus.

The taxonomic inference combining a BLASTN search and the importation of moderate Sanger sequence data into the standard NGS metagenomic pipeline resulted in congruent and reliable taxa assignation.

All these species have been previously isolated and studied from dairy products, such as cow's milk, goat's milk, and sheep's milk [39, 41-45]. Another study aimed at characterizing the bacterial community of donkey milk and showed that the basic microbiota was composed of genera including LAB and species typically present in plants, soil, and water [46].

3.4. Antibacterial Activity. The LABs were put under different culture conditions to optimize the production of the antibacterial substances; the inhibitory spectra of these bacteria are given in Table 3 .

These results reveal that the supernatants of the 5 studied strains show an inhibition against the pathogenic indicator strains, with the exception of Aerococcus viridans and Enterococcus viikkiensis. These species showed a weak inhibition under different culture conditions against Staphylococcus aureus and Escherichia coli, respectively. All strains exhibited significant inhibition against Listeria monocytogenes. The maximum activity was observed with Tween 20, UV, and in coculture with Listeria with diameters of 28, 20, and $21 \mathrm{~mm}$ respectively. Subsequent studies have demonstrated the ability of Tween 20 to increase bacteriocin production and as a result demonstrated inhibitory activity in its presence [47-49]. Furthermore, another study has shown that the regulation of bacteriocin expression depends on an external stimulus such as cocultivation with other strains [50]. Referring to the controls (Table S2), the inhibitory activity observed in the presence of SDS appears to be caused by SDS itself and not by lactic acid strains. This hypothesis has been confirmed by Chen and Yanagida [51]. 
TABLE 1: The different culture conditions for the evaluated strains.

\begin{tabular}{lc}
\hline Methods & Modified media \\
\hline 1 & $2.5 \%$ yeast extract \\
2 & $0.5 \%$ glucose \\
3 & Manganese $(0.033$ mm) \\
4 & Ultraviolet \\
5 & SDS \\
6 & $1 \%$ Tween 20 \\
7 & Coculture with L. monocytogenes \\
8 & EDTA \\
\hline
\end{tabular}

TABLE 2: Results of physicochemical parameters of donkey's milk.

\begin{tabular}{lr}
\hline Test & Result \\
\hline $\mathrm{pH}$ & 7.1 \\
Titrable acidity & $16.3^{\circ} \mathrm{D}$ \\
Dry matter & $127 \mathrm{~g} / \mathrm{L}$ \\
Density & 1,032 \\
\hline
\end{tabular}

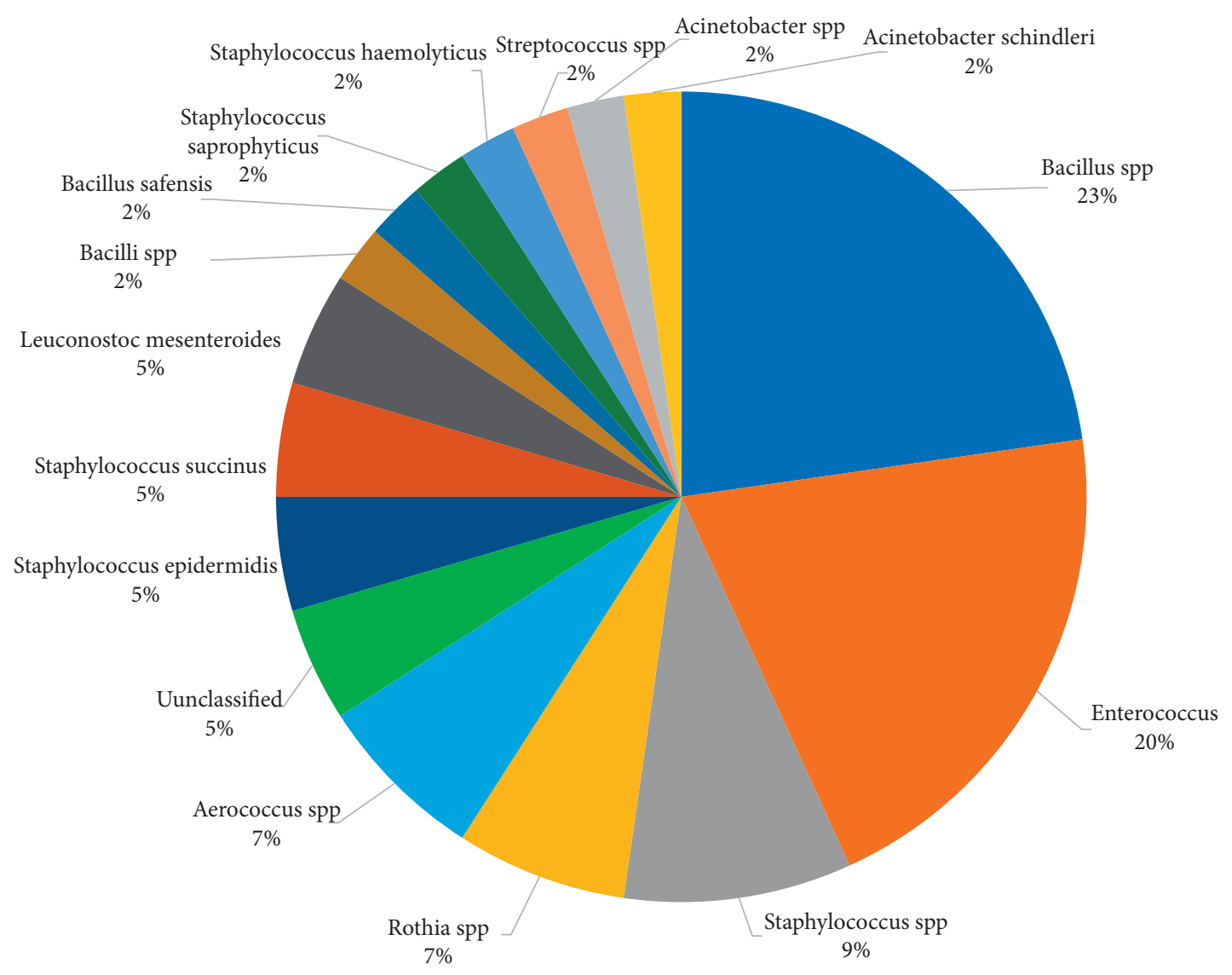

FIGURE 1: Taxonomic inference of donkey milk bacteria and the relative abundance of recovered sequences. 


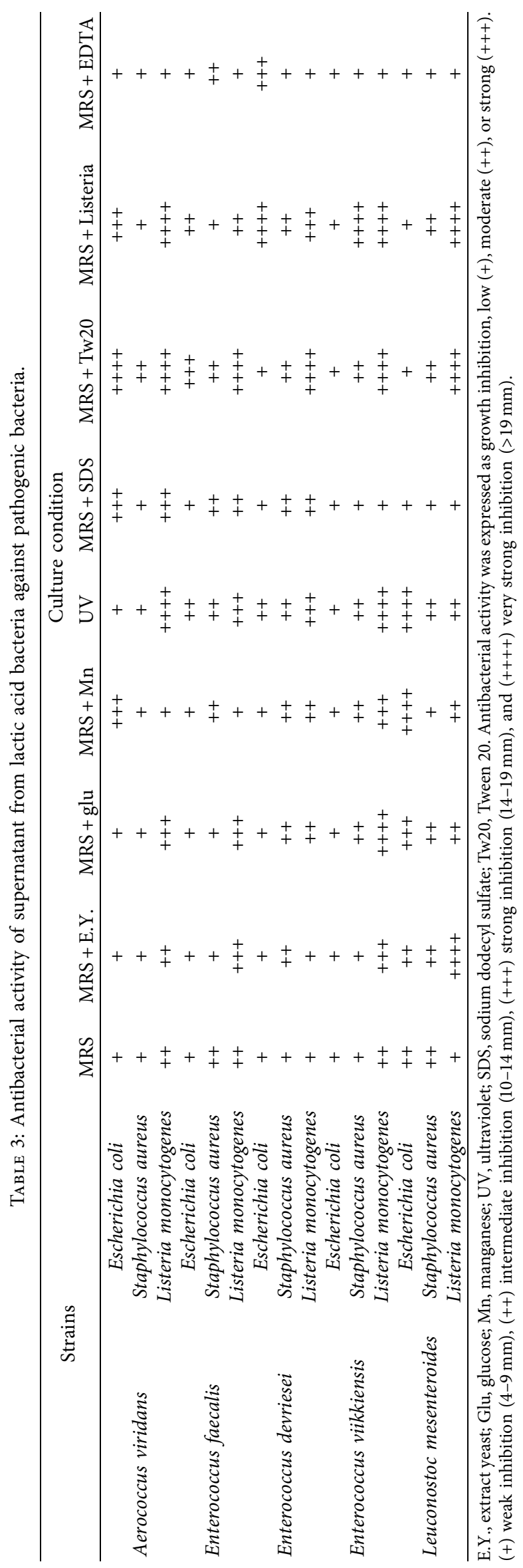




\section{Conclusion}

The present study has shown that the five lactic strains tested are capable of producing active biomolecules with inhibitory activity on the pathogenic strains: Listeria monocytogenes, Escherichia coli, and Staphylococcus aureus. This antibacterial activity could be due to the production of bacteriocins or other biomolecules. Studies are underway to characterize and identify these antimicrobial compounds.

\section{Data Availability}

The microbiological and molecular data used to support the findings of this study are available from the corresponding author upon request.

\section{Conflicts of Interest}

The authors declare that they have no conflicts of interest.

\section{Supplementary Materials}

The supplementary material of the research article "Isolation and identification of bacterial population of donkey milk from a region of Morocco by QIIME 2 and evaluation of their biomolecules" by Derdak et al. is composed by two tables. Table S1: phenotypic and biochemical characteristics of isolated lactic bacteria. Table S2: blanks for Staphylococcus aureus. (Supplementary Materials)

\section{References}

[1] C. Neut, S. Mahieux, and L. J. Dubreuil, "Antibiotic susceptibility of probiotic strains: is it reasonable to combine probiotics with antibiotics?" Medecine et Maladies Infectieuses, vol. 47, no. 7, pp. 477-483, 2017.

[2] J. Romero, E. Ibargüen, and L. Esteva, "Modeling mathematically the influence of plasmids on the propagation of bacterial resistance to antibiotics," Biomath Communications Supplement, vol. 5, no. 1, 2018.

[3] World Health Organization (WHO), "Antimicrobial resistance," WHO, Geneva, Switzerland, 2021, https://apps.who. int/gb/ebwha/pdf_files/WHA72/A72_R5-en.pdf?ua=1.

[4] G. Huys, H.-M. Daniel, and L. De Vuyst, "Taxonomy and biodiversity of sourdough yeasts and lactic acid bacteria," in Handbook on Sourdough Biotechnology, M. Gobbetti and M. Gänzle, Eds., Springer, Boston, MA, USA, pp. 105-154, 2013.

[5] Z. Erginkaya, E. Ünal, and S. Kalkan, "Microbial metabolites as biological control agents in food safety," in Food Engineering Series, pp. 225-259, Springer, Berlin, Germany, 2014.

[6] S. Sakoui, R. Derdak, B. Addoum, A. Serrano-Delgado, A. Soukri, and B. El Khalfi, "The life hidden inside caves: ecological and economic importance of bat guano," International Journal of Ecology, vol. 2020, Article ID 9872532, 7 pages, 2020.

[7] S. da Silva Sabo, M. Vitolo, J. M. D. González, and R. P. d. S. Oliveira, "Overview of Lactobacillus plantarum as a promising bacteriocin producer among lactic acid bacteria," Food Research International, vol. 64, pp. 527-536, 2014.
[8] M. G. Gänzle, "Lactic metabolism revisited: metabolism of lactic acid bacteria in food fermentations and food spoilage," Current Opinion in Food Science, vol. 2, pp. 106-117, 2015.

[9] J. A. Reis, A. T. Paula, S. N. Casarotti, and A. L. B. Penna, "Lactic acid bacteria antimicrobial compounds: characteristics and applications," Food Engineering Reviews, vol. 4, no. 2, pp. 124-140, 2012.

[10] P. M. Moraes, L. M. Perin, M. B. Tassinari Ortolani, A. K. Yamazi, G. N. Viçosa, and L. A. Nero, "Protocols for the isolation and detection of lactic acid bacteria with bacteriocinogenic potential," LWT-Food Science and Technology, vol. 43, no. 9, pp. 1320-1324, 2010.

[11] J. C. Slootweg, E. F. Van Herwerden, M. F. M. Van Doremalen, E. Breukink, R. M. J. Liskamp, and D. T. S. Rijkers, "Synthesis of nisin AB dicarba analogs using ring-closing metathesis: influence of sp3versus sp2hybridization of the $\alpha$-carbon atom of residues dehydrobutyrine- 2 and dehydroalanine- 5 on the lipid II binding affinity," Organic and Biomolecular Chemistry, vol. 13, no. 21, pp. 59976009, 2015.

[12] C. J. González-Pérez, E. Aispuro-Hernández, I. Vargas-Arispuro, and M. A. Martínez-Téllez, "Induction of bacteriocins from lactic acid bacteria; a strategy to improve the safety of fresh fruits and vegetables," Agricultural Research \& Technology: Open Access Journal, vol. 14, no. 4, 2018.

[13] L. De Vuyst and F. Leroy, "Bacteriocins from lactic acid bacteria: production, purification, and food applications," Journal of Molecular Microbiology and Biotechnology, vol. 13, no. 4, pp. 194-199, 2007.

[14] W. Woraprayote, Y. Malila, S. Sorapukdee, A. Swetwiwathana, S. Benjakul, and W. Visessanguan, "Bacteriocins from lactic acid bacteria and their applications in meat and meat products," Meat Science, vol. 120, pp. 118-132, 2016.

[15] T. Teneva-Angelova, I. Hristova, A. Pavlov, and D. Beshkova, "Lactic acid bacteria-from nature through food to health," Advances in Biotechnology for Food Industry, vol. 14, pp. 91133, 2018.

[16] D. Carminati and F. Tidona, "Nutritional value and potential health benefits of donkey milk," Nutrients in Dairy and their Implications on Health and Disease, pp. 407-414, 2017.

[17] S. Vincenzetti, S. Pucciarelli, V. Polzonetti, and P. Polidori, "Role of proteins and of some bioactive peptides on the nutritional quality of donkey milk and their impact on human health," Beverages, vol. 3, no. 4, p. 34, 2017.

[18] M. Aspri, N. Economou, and P. Papademas, "Donkey milk: an overview on functionality, technology, and future prospects," Food Reviews International, vol. 33, no. 3, pp. 316-333, 2017.

[19] M. Martini, I. Altomonte, R. Licitra, and F. Salari, "Nutritional and nutraceutical quality of donkey milk," Journal of Equine Veterinary Science, vol. 65, pp. 33-37, 2018.

[20] M. D. L. D. Soto Del Rio, C. Andrighetto, A. Dalmasso, A. Lombardi, T. Civera, and M. T. Bottero, "Isolation and characterisation of lactic acid bacteria from donkey milk," Journal of Dairy Research, vol. 83, no. 3, pp. 383-386, 2016.

[21] K. Raynal-Ljutovac, Y. W. Park, F. Gaucheron, and S. Bouhallab, "Heat stability and enzymatic modifications of goat and sheep milk," Small Ruminant Research, vol. 68, no. 12, pp. 207-220, 2007.

[22] AFNOR, Contrôle de la Qualité des Produits Alimentaires: Lait et Produits Laitiers: Analyses Physico-Chimiques, AFNOR, Paris, France, 1993. 
[23] D. H. Bergey, "Genus trichodesmium," in Bergey's Manual of Determinative Bacteriology, J. G. Holt, Ed., pp. 395-396, Williams \& Wilkins, Philadelphia, PA, USA, 1994.

[24] B. Elkhalfi, A. Essari, A. Serrano, and A. Soukri, "Antibacterial activity of plant methanolic extracts on a field isolate of Pseudomonas syringae pvtomato from the Casablanca region (Morocco)," Advances in Bioscience and Biotechnology, vol. 4, no. 7, pp. 1-9, 2013.

[25] I. Mardad, A. Serrano, and A. Soukri, "Solubilization of inorganic phosphate and production of organic acids by bacteria isolated from a Moroccan mineral phosphate deposit," African Journal of Microbiology Research, vol. 7, no. 8, pp. 626-635, 2013.

[26] T. Hall, "BioEdit: a user-friendly biological sequence alignment editor and analysis program for windows 95/98/NT," Nucleic Acids Symposium Series, vol. 41, pp. 95-98, 1999.

[27] E. Bolyen, J. Rideout, M. Dillon et al., "QIIME 2: reproducible, interactive, scalable, and extensible microbiome data science," Nature Biotechnology, vol. 37, no. 8, pp. 852-857, 2018.

[28] K. Katoh, K. Misawa, K. Kuma, and T. Miyata, "MAFFT: a novel method for rapid multiple sequence alignment based on fast Fourier transform," Nucleic Acids Research, vol. 30, no. 14, pp. 3059-3066, 2002.

[29] M. N. Price, P. S. Dehal, and A. P. Arkin, "FastTree 2-approximately maximum-likelihood trees for large alignments," PLoS One, vol. 5, no. 3, Article ID e9490, 2010.

[30] N. A. Bokulich, B. D. Kaehler, J. R. Rideout et al., "Optimizing taxonomic classification of marker-gene amplicon sequences with QIIME 2's q2-feature-classifier plugin," Microbiome, vol. 6, no. 1, p. 90, 2018.

[31] D. McDonald, M. N. Price, J. Goodrich et al., “An improved greengenes taxonomy with explicit ranks for ecological and evolutionary analyses of bacteria and archaea," The ISME Journal, vol. 6, no. 3, pp. 610-618, 2012.

[32] M. Johnson, I. Zaretskaya, Y. Raytselis, Y. Merezhuk, S. McGinnis, and T. L. Madden, "NCBI blast: a better web interface," Nucleic Acids Research, vol. 36, pp. W5-W9, 2008.

[33] U. Schillinger and F. K. Lücke, "Antibacterial activity of Lactobacillus sake isolated from meat," Applied and Environmental Microbiology, vol. 55, no. 8, pp. 1901-1906, 1989.

[34] J. L. Maubois, "Incidence de l'utilisation du sometribove, somatotropine bovine méthionylée recombinée, sur les propriétés technologiques du lait de vache et sur les qualités organoleptiques des produits résultants," Dairy Science \& Technology, vol. 70, no. 5-6, pp. 369-382, 1990.

[35] S. Ozturkoglu-Budak, "Effect of different treatments on the stability of lysozyme, lactoferrin and $\beta$-lactoglobulin in donkey's milk," International Journal of Dairy Technology, vol. 71, no. 1, pp. 36-45, 2018.

[36] H. Y. Guo, K. Pang, X. Y. Zhang et al., "Composition, physiochemical properties, nitrogen fraction distribution, and amino acid profile of donkey milk," Journal of Dairy Science, vol. 90, no. 4, pp. 1635-1643, 2007.

[37] E. Salimei, "Animals that produce dairy foods: donkey," Reference Module in Food Science, Elsevier, Amsterdam, Netherlands, 2016.

[38] H. E.-H. El-Hatmi, Z. Jrad, I. Salhi, A. Aguibi, A. Nadri, and T. Khorchani, "Comparison of composition and whey protein fractions of human, camel, donkey, goat and cow milk," Mljekarstvo, vol. 65, no. 3, pp. 159-167, 2015.

[39] M. L. de Garnica, J. A. Sáez-Nieto, R. González, J. A. Santos, and C. Gonzalo, "Diversity of gram-positive catalase-negative cocci in sheep bulk tank milk by comparative $16 \mathrm{~S}$ rDNA sequence analysis," International Dairy Journal, vol. 34, no. 1, pp. 142-145, 2014.

[40] D. Carminati, F. Tidona, M. E. Fornasari, L. Rossetti, A. Meucci, and G. Giraffa, "Biotyping of cultivable lactic acid bacteria isolated from donkey milk," Letters in Applied Microbiology, vol. 59, no. 3, pp. 299-305, 2014.

[41] K. E. Sutyak, R. E. Wirawan, A. A. Aroutcheva, and M. L. Chikindas, "Isolation of the Bacillus subtilis antimicrobial peptide subtilosin from the dairy product-derived Bacillus amyloliquefaciens," Journal of Applied Microbiology, vol. 104, no. 4, pp. 1067-1074, 2008.

[42] M. W. Griffiths, "Toxin production by psychrotrophic Bacillus spp. present in milk," Journal of Food Protection, vol. 53, no. 9, pp. 790-792, 1990.

[43] M. Deinhofer and A. Pernthaner, "Staphylococcus spp. as mastitis-related pathogens in goat milk," Veterinary Microbiology, vol. 43, no. 2-3, pp. 161-166, 1995.

[44] G. Giraffa, D. Carminati, and E. Neviani, "Enterococci isolated from dairy products: a review of risks and potential technological use," Journal of Food Protection, vol. 60, no. 6, pp. 732-738, 1997.

[45] A. Terzić-Vidojević, K. Veljović, J. Begović et al., "Diversity and antibiotic susceptibility of autochthonous dairy enterococci isolates: are they safe candidates for autochthonous starter cultures?" Frontiers in Microbiology, vol. 6, p. 954, 2015.

[46] M. d. 1. D. Soto del Rio, A. Dalmasso, T. Civera, and M. T. Bottero, "Characterization of bacterial communities of donkey milk by high-throughput sequencing," International Journal of Food Microbiology, vol. 251, pp. 67-72, 2017.

[47] M. P. Ryan, W. J. Meaney, R. P. Ross, and C. Hill, "Evaluation of Lacticin 3147 and a teat seal containing this bacteriocin for inhibition of mastitis pathogens," Applied and Environmental Microbiology, vol. 64, no. 6, pp. 2287-2290, 1998.

[48] B. G. Contreras, L. De Vuyst, B. Devreese et al., "Isolation, purification, and amino acid sequence of Lactobin A, one of the two bacteriocins produced by Lactobacillus amylovorus LMG P-13139," Applied and Environmental Microbiology, vol. 63, no. 1, pp. 13-20, 1997.

[49] T. Keren, M. Yarmus, G. Halevy, and R. Shapira, "Immunodetection of the bacteriocin lacticin RM: analysis of the influence of temperature and tween 80 on its expression and activity," Applied and Environmental Microbiology, vol. 70, no. 4, pp. 2098-2104, 2004.

[50] A. Maldonado, R. Jiménez-Díaz, and J. L. Ruiz-Barba, "Induction of plantaricin production in Lactobacillus plantarum NC8 after coculture with specific gram-positive bacteria is mediated by an autoinduction mechanism," Journal of Bacteriology, vol. 186, no. 5, pp. 1556-1564, 2004.

[51] Y.-S. Chen and F. Yanagida, "Characteristics and effects of temperature and surfactants on bacteriocin-like inhibitory substance production of soil-isolated Lactobacillus animalis C060203," Current Microbiology, vol. 53, no. 5, pp. 384-387, 2006. 